\title{
The Securities Exchange Act and the Rule of Exclusive Federal Jurisdiction
}

Rules establishing exclusive jurisdiction of specific legal claims are designed to provide judges and litigants clear guidance in determining the forum in which a suit should be brought. A statutory grant of exclusive jurisdiction can minimize the cost of threshold litigation generated by the need to define the appropriate forum for adjudication. The modern development of the transactional case, ${ }^{1}$ however, is not easily reconciled with exclusive jurisdiction; federal, state, and common law claims regularly merge to form the basis for litigation. ${ }^{2}$ The economies realized by the expansive concept of a case thus conflict with the efficient jurisdictional rule of exclusivity.

The tensions between procedural reform ${ }^{3}$ and a jurisdictional pattern premised on the segregation of federal and state law claims are illustrated by the problems generated by the exclusive jurisdiction of the Securities Exchange Act of 1934. ${ }^{4}$ In particular, this tension is manifested by the disparate treatment of defenses and counterclaims arising under the Exchange Act. Although a state court may adjudicate an Exchange Act defense, it is not permitted to hear an Exchange Act counterclaim. This semi-exclusivity engenders a litigation pat-

I. The transactional case refers to a unitary adjudication which resolves multiple disputes arising from a given set of facts. Transactional cases are possible for two reasons. First, federal courts may exercise broad discretion in accepting state law claims as pendent to federal causes of action. See UMW v. Gibbs, 383 U.S. 715, 725 (1966) (federal courts have "power" to hear state and federal claims derived from common operative facts). Second, the Federal Rules of Civil Procedure provide for liberal joinder of all parties, claims, and remedies relevant to the same factual transaction. See FED. R. CIv. P. 18-20. See generally F. James \& G. Hazard, CiviL Procedure 20-22 (2d ed. 1977) [hereinafter cited as JAMES \& HAZARD].

2. See, e.g., UMW v. Gibbs, 383 U.S. 715, 727 (1966) (discussing close relation in certain situations of state and federal claims).

3. Culminating in the transactional case, see note I supra, the movement for procedural reform was premised largely on the acceptance of liberal pleading rules. With the adoption in 1938 of the Federal Rules of Civil Procedure, the federal system rejected both the formulaic common law pleadings and the law/fact distinction demanded of "code" complaints. The modern rules simply require that federal complaints "contain - . a short and plain statement of the claim showing that the pleader is entitled to relief ..." FED. R. CIV. P. 8(a)(2). See generally JAMES \& HAZARD, supra note 1, at 62-88.

4. I5 U.S.C. $\$ \S 78 a-78$ iii (1976). The jurisdictional section is $\$ 78 a a$. 
tern with consequences harmful to both Exchange Act litigants and courts.

This Note argues that the problems fostered by the inherent tension between exclusive jurisdiction and the transactional case cannot be resolved solely by a reallocation of jurisdiction; only by integrating a clear jurisdictional scheme with procedural protection can a solution be designed. The Note proposes an amendment to the Exchange Act that would permit state court adjudication of both Exchange Act defenses and counterclaims, and would also require the application of federal procedural safeguards to all issues arising under the federal statute. Such an amendment would both fulfill the policies underlying federal jurisdiction and reconcile the tension between the need for clear jurisdictional rules and the economies of the transactional case.

\section{The Breakdown of Exclusivity}

Section 27 of the Exchange Act provides for exclusive federal jurisdiction of claims arising under the Act. ${ }^{5}$ This provision was presumably intended to establish a clear and efficient allocation of responsibility between the state and federal judicial systems. ${ }^{6}$ In erecting a barrier to state court adjudication, the section 27 grant of exclusive federal jurisdiction presumed to define unambiguously the jurisdictional consequences arising from the assertion of an Exchange Act claim.

The emergence of the transactional case, however, brought into question the rule of exclusive federal jurisdiction as it had developed under the Exchange Act. Although the rule of exclusivity has prevented the intrusion of plaintiffs' Exchange Act claims into state courts, $^{7}$ the pressures for unitary litigation have further obscured an

5. Securities Exchange Act of 1934, § 27, 15 U.S.C. $§ 78$ aa (1976). Section 27 states: The district courts of the United States ... shall have exclusive jurisdiction of violations of this chapter or the rules and regulations thereunder, and of all suits in equity and actions at law brought to enforce any liability or duty created by this chapter or the rules and regulations thereunder.

6. Examination of the legislative history of the Exchange Act suggests that the 1934 Congress did not consider carefully the advantages of a rule providing for exclusive federal jurisdiction. See note 58 infra.

7. In the course of dismissing plaintiff Exchange Act claims, state courts have consistently indicated that Exchange Act plaintiff actions can only be heard within a federal forum. See, e.g., Webster v. Steinberg, 84 Nev. 426, 429, 442 P.2d 894, 896 (1968); Eliasberg v. Standard Oil Co., 23 N.J. Super. 431, 444, 92 A.2d 862, 869 (Super. Ct. Ch. Div. 1952), aff'd, 12 N.J. 467, 97 A.2d 437 (1953); American Distilling Co. v. Brown, 295 N.Y. $36,41-42,64$ N.E.2d 347,349 (1945). 
already clouded vision of exclusivity on the defendants' side: long standing principles of procedure require state courts to hear federal defenses, ${ }^{8}$ but not federal counterclaims. ${ }^{9}$ Thus, exclusive jurisdiction under section 27 is incomplete: a state court must exercise jurisdiction over defenses based on the Act ${ }^{10}$ and can award equitable relief on the

8. In 1897, the Supreme Court held that state courts may adjudicate "questions" arising under exclusive acts. Pratt v. Paris Gas Light \& Coke Co., 168 U.S. 255, 259 (1897) (clear distinction between exclusive act "case"-plaintiff action-which must be heard in federal court and exclusive act "question"--defense-which may be raised in state forum). See generally D. Currie, Federal Courts $373-80$ (2d ed. 1975); P. Bator, P. Mishikin, D. Shapiro, \& H. Wechsler, Hart and Wechsler's The Federal Courts and the Federal SYSTEM 431-38, 874-79 (2d ed. 1973) [hereinafter cited as HART \& WECHSLER].

The value of the Court's "clear distinction" between cases and questions arising under exclusive acts is diminished by the integral relation of exclusive act defenses and affirmative claims. While a state defendant may raise an exclusive act defense, the litigant cannot plead in the state forum an affirmative counterclaim based on the same exclusive act, see note 9 infra.

In the context of Exchange Act claims, the Supreme Court has specifically recognized state court jurisdiction of Exchange Act defenses. See Will v. Calvert Fire Ins. Co., 437 U.S. 655, 660 n.3 (1978) (plurality opinion of Rehnquist, J.) (arising in mandamus case involving parallel state and federal securities law actions). Without evaluating such precedents as Pratt, the Supreme Court did not dispute state court jurisdiction of an Exchange Act defense.

Numerous lower federal decisions concur in the Will approach. See, e.g., Calvert Fire Ins. Co. v. American Mutual Reinsurance Co., 600 F.2d 1228, 1231 (7th Cir. 1979) ("we have interpreted Section 27 of the 1934 Act to allow concurrent jurisdiction in the state court of 1934 Act defenses to a state cause of action") (footnote omitted); Weiner v. Shearson, Hammill \& Co., 521 F.2d 817, 822 (9th Cir. 1975) (state court had jurisdiction to rule on Exchange Act issues as a matter of affirmative defense to a state defendant's counterclaim); McGough v. First Arlington Nat'l Bank, 519 F.2d 552, 555 n.1 (7th Cir. 1975) (exclusive jurisdiction of Exchange Act does "not preclude a state court defendant from pleading, and a state court from recognizing, an affirmative defense of illegality under the Act").

9. See, e.g., Will v. Calvert Fire Ins. Co., 437 U.S. 655, 666 (1978) (claim for affirmative Exchange Act relief-damages-can only be adjudicated in federal court); Calvert Fire Ins. Co. v. American Mutual Reinsurance Co., 600 F.2d 1228, 1231 (7th Cir. 1979) ("jurisdiction over claims for affirmative relief under the Act is exclusively vested in the federal courts"); Weiner v. Shearson, Hammill \& Co., 521 F.2d 817, 824 (9th Cir. 1975) (serious doubt as to state court's jurisdiction to try affirmative relief under Exchange Act); McGough v. First Arlington Nat'l Bank, 519 F.2d 552, 555 (7th Cir. 1975) (affirmative federal remedies cannot be awarded in "sterile state court").

One decision has ambiguously suggested that state courts are competent to adjudicate "historical facts" underlying an Exchange Act counterclaim. See Colter v. Inter-County Orthopaedic Ass'n, 526 F.2d 537, 542 (3d Cir. 1975) ("state court may be able to determine the historical facts in this ongoing dispute" involving parallel state and federal securities claims).

10. State court acceptance of jurisdiction over Exchange Act defenses has been most prevalent in the context of margin requirement litigation. See, e.g., Gregory-Massari, Inc. v. Purkitt, I Cal. App. 3d 968, 82 Cal. Rptr. 210 (1969); J. Cliff Rahel \& Co. v. Roper, 186 Neb. 34, 180 N.W. $2 d 682$ (1970). Jurisdiction over $\S 10(b)$ antifraud defenses has also been exercised. See, e.g., Southern Brokerage Co. v. Cannarsa, 405 S.W.2d 475 (Tex. Civ. App. 1966), cert. denied, 386 U.S. 1004 (1967). See generally 4 A. BromBERG, Securities LAW 244.11 (Supp. 1974). For analysis of state court margin requirement adjudication, see pp. 112-13 infra.

Despite the Supreme Court's interpretation of exclusive jurisdiction in Pratt v. Paris 


\section{basis of a successful Act defense. ${ }^{11}$}

The pattern of litigation culminating in Will $v$. Calvert Five Insurance Co. ${ }^{12}$ illustrates the antagonism of the theory of the transactional case and the rule of exclusive jurisdiction. The state court plaintiff, American Mutual Reinsurance Co., brought suit to obtain an order that an agreement was effective despite defendant Calvert Fire Insurance Co.'s rescission of the agreement. ${ }^{13}$ In its answer, the defendant aggregated defenses premised on state securities law and on two federal securities acts-the Securities Act of $1933^{14}$ [1933 Act] and the Exchange Act. ${ }^{15}$ Due to the exclusive jurisdiction of the Exchange Act, however, the state defendant was limited in its counterclaim to an action grounded in state law and the 1933 Act, ${ }^{16}$ which provides for concurrent jurisdiction. ${ }^{17}$ As a result of this disparate treatment

Gas Light \&. Coke Co., 168 U.S. 255 (1897), see note 8 supra, certain anomalous cases have construed section 27 as mandating rejection of a state court defendant's Exchange Act defense. See Reuben Rose \& Co. v. Davon Assoc., [1967-1969 Transfer Binder] FED. SEC. L. REP. (CCH) I 92,109 (N.Y. Sup. Ct. 1967) (affirmative defenses and counterclaims based on violations of Exchange Act dismissed); Investment Assoc. v. Standard Power \& Light Corp., 29 Del. Ch. 225, 48 A.2d 501 (Ch. 1946), aff'd, 29 Del. Ch. 593, 51 A.2d 572 (Del. 1947) (violation of Exchange Act proxy regulations could not be raised as defense in suit to review corporate election). For discussion of the question of state court defense jurisdiction, see Loss, The SEC Proxy Rules and State Law, 73 Harv. L. REv. 1249, 1254-57 (1960); Note, The Effect of Prior Nonfederal Proceedings on Exclusive Federal Jurisdiction Over Section $10(b)$ of the Securities Exchange Act of 1934, 46 N.Y.U. L. REv. 936, 937-38 (1971) [hereinafter cited as Nonfederal Proceedings].

11. See Will v. Calvert Fire Ins. Co., 437 U.S. 655, 666 n.9 (1978) (state court has jurisdiction to award equitable relief of rescission); Calvert Fire Ins. Co. v. American Mutual Reinsurance Co., 600 F.2d 1228, 1230 (7th Cir. 1979) (same). Other federal courts appear to be confused as to whether state court jurisdiction of an Exchange Act affirmative defense of illegality is equivalent to the equitable relief of rescission. See, e.g., Weiner v. Shearson, Hammill \& Co., 521 F.2d 817, 822 (9th Cir. 1975) (recognizes state court jurisdiction of affirmative defense but does not specifically indicate whether state court may award equitable relief); McGough v. First Arlington Nat'l Bank, 519 F.2d 552, 554-55, 555 n.1 (7th Cir. 1975) (fails to elucidate whether "exclusive federal remedy sought under the complaint in the District Court [that] is not available ... in the State action" is rescission or money damages). But see Movielab, Inc. v. Berkey Photo, Inc., 321 F. Supp. 806, 811 (S.D.N.Y. 1970), aff'd, 452 F.2d 620 (2d Cir. 1971) (appears to suggest that rescission is an "affirmative claim").

12. 437 U.S. 655 (1978). For the subsequent history of the case as remanded, see note 25 infra.

13. 437 U.S. at 658.

14. I5 U.S.C. $\$ \S 77 a-77 a a$ (1976).

15. 437 U.S. at 658. Calvert's answer premised on 1933 Act and Exchange Act grounds was not filed until six months after the state plaintiff had initiated suit. Had Calvert answered within thirty days, it would have been able to remove the case to federal court on the basis of diversity of citizenship. See 28 U.S.C. $\$ \S 1441,1446$ (a), (b) (1976). For discussion of Calvert's failure to remove, see Calvert Fire Ins. Co. v. American Mutual Reinsurance Co., 459 F. Supp. 859, 862 \& n.3, 864 (N.D. Ill. 1978), aff'd, 600 F.2d I228, 1232 \& n.10 (7th Cir. 1979).

16. 437 U.S. at 658.

17. See $\S 22(a), 15$ U.S.C. $\$ 77 v(a)(1976)$. 
of Exchange Act defenses and counterclaims, the state defendant could preserve its Exchange Act damages remedy only by bifurcating its affirmative claims. Contemporaneous with its answer, therefore, the state defendant entered federal court as an Exchange Act plaintiff. ${ }^{18}$

In an attempt to confine litigation to the initial forum, the state plaintiff sought to dismiss or stay the federal action. ${ }^{19}$ Believing that parallel litigation would be both duplicative and wasteful, the district court stayed all elements of the federal proceeding with the exception of the federal plaintiff's "exclusive" Exchange Act claim..$^{20}$ Nevertheless, the district court delayed in adjudicating the exclusive federal claim. ${ }^{21}$ Frustrated by what was an effective stay of the entire federal proceedings, ${ }^{22}$ the federal plaintiff petitioned the Court of Appeals for the Seventh Circuit for a writ of mandamus directing District Court Judge Will to proceed with adjudication of the Exchange Act claims. ${ }^{23}$ The Seventh Circuit granted the petition. ${ }^{24}$ Finding that the district court had not heedlessly refused to proceed with plaintiff's Exchange Act claims, a sharply split Supreme Court reversed. ${ }^{25}$ State litigation in Calvert has been equally protracted; five

18. 437 U.S. at 658 .

19. Id. at 659 .

20. Id. at 659-60. For discussion of stays of parallel federal actions, see note 40 infra.

21. Following his stay order, District Court Judge Will did hear oral argument "on the basic question of whether Calvert's interest in the reinsurance pool . . [was] a security within the meaning of the 1934 Act." 437 U.S. at 660 (Supreme Court review of case's procedural history). However, the Judge failed to issue a ruling on this question. Id. (District Court decision outstanding at time of Supreme Court review of Seventh Circuit mandamus order). Meanwhile in the parallel state proceeding, Illinois Circuit Court Judge Dunne ruled (approximately one month after Judge Will's stay order) that the reinsurance agreement was not a security within the meaning of the federal securities laws. See American Mutual Reinsurance Co. v. Calvert Fire Ins. Co., 52 Ill. App. 3d 922, 367 N.E.2d 104 (1977), cert. denied, 436 U.S. 906 (1978) (Illinois Appellate Court affirmance on interlocutory appeal of trial judge's ruling); Weissman, Reinsurance Pools and the Federal Securities Laws, 9 Lox. CHI. L.J. 313, 314-15 (1978). Following the state trial judge's order, "[a]t that point, and not before, Judge Will apparently decided informally on his own motion to postpone decision on the federal security question." Calvert Fire Ins. Co. v. American Mutual Reinsurance Co., 600 F.2d 1228, 1231 (7th Cir. 1979).

22. In its original mandamus opinion, see notes 23-24 infra, the Seventh Circuit concluded that the actions of Judge Will were "equivalent to a dismissal for purposes of this case." Calvert Fire Ins. Co. v. Will, 560 F.2d 792, 796 (7th Cir. 1977).

23. 437 U.S. at 660.

24. Calvert Fire Ins. Co. v. Will, 560 F.2d 792, 797 (7th Cir. 1977).

25. 437 U.S. at 667 . While five Justices concurred in the reversal and remand, no more than four Justices joined in any one opinion. Writing for Justices Stewart, White, and Stevens, Justice Rehnquist indicated that the decision to defer to state court proceedings was "largely committed to the discretion of the District Court." 437 U.S. at 664. Only proof of a "heedless refusal to proceed" could support the extraordinary relief of mandamus. 437 U.S. at 666-67. Justice Blackmun concurred in the judgment on much more narrow grounds. As Judge Will issued the stay order prior to the Supreme Court's opinion in Colorado River Water Conservation Dist. v. United States, 424 U.S. 800 (1976) 
years after initiation of the state action, final decision on the trial level remains outstanding. ${ }^{2 \mathrm{~B}}$

\section{The Failure of Exchange Act Exclusive Jurisdiction}

Although the anomalous treatment of defenses and counterclaims establishes that exclusive jurisdiction is incomplete, this development alone is no cause for serious concern. However, analysis of the litigation obstacles and alternatives encountered by the parties in Will demonstrates that semi-exclusivity, at least as it operates in the context of the Exchange Act, has a serious, detrimental impact on the protection of Exchange Act rights and on judicial economy. By providing that certain federal claims would be heard in a federal forum, the rule of exclusive federal jurisdiction ensures that a federal claimant enjoys whatever benefits a federal judge and federal procedure offer. This rule also lowers the costs of establishing the appropriate forum for adjudication. However, the collision of the transactional case with the rule of exclusive jurisdiction has frustrated realization of these fundamental goals.

\section{A. Prejudice to Exchange Act Claims}

The state defendant in Will was compelled to raise his Exchange Act defense to avoid an adverse judgment; ${ }^{27}$ because he could not

(outlining appropriate grounds for dismissing federal action that parallels state suit; stay of federal action not considered), "The Court of Appeals should have done no more than require reconsideration of the case by Judge Will in light of Colorado River." 437 U.S. at 668 (Blackmun, J., concurring in judgment). Chief Justice Burger and Justices Brennan, Marshall, and Powell dissented from the Court's judgment. For analysis of the impact of Colorado River on the Will opinions, see Note, Abstention and Mandamus After Will v. Calvert Fire Insurance Co., 64 CoRNel. L. REv. 566, 579-85 (1979); 24 VILL. L. REv. 815, 820-24 (1979).

On remand, the Seventh Circuit interpreted the Supreme Court's decision along the narrow lines suggested by Justice Blackmun's opinion. Calvert Fire Ins. Co. v. Will, 586 F.2d 12, 14 (1978) (on its own motion district court will "reconsider its actions . . . in light of Colorado River"). After reviewing his original stay ruling, Judge Will ordered continuation of the stay largely on the basis of Calvert's admission in Supreme Court oral argument as to its inability to recover on its affirmative $\$ 10 \mathrm{~b}$ damages claim, 459 F. Supp. 859, 861-63 (N.D. Ill. 1978), aff'd, 600 F.2d 1228, 1236 (7th Cir. 1979).

26. See Calvert Fire Ins. Co. v. American Mutual Reinsurance Co., 600 F.2d 1228, 1236 (7th Cir. 1979); telephone conversation with bailiff for Illinois Circuit Court (Cook County) Judge Dunne (October 2, 1979) (notes on file with Yale Law Journal).

On Calvert's motion in state court, discovery had been stayed in the state proceedings pending Supreme Court review of the Seventh Circuit's mandamus order. See Calvert Fire Ins. Co. v. American Mutual Reinsurance Co., 459 F. Supp. 859, 864 \& n.5 (N.D. Ill. 1978), aff'd, 600 F.2d 1228, 1234 \& n.14 (7th Cir. 1979).

27. A state defendant may be forced to raise an Exchange Act defense due to the absence of state or common law analogues. For example, Exchange Act margin regulations may provide the only available defense to a broker's state suit based on a deficiency in a 
raise the related counterclaim, however, he was obliged to bring a simultaneous suit in federal court. ${ }^{28}$ The problem of duplicative litigation is compounded by two interrelated factors: the federal tribunal is likely to accord collateral estoppel ${ }^{29}$ effect to important findings of fact developed in the state court adjudication of the Exchange Act defense, and these state-determined facts may be the product of state discovery rules that are less liberal than the federal rules. To avoid prejudice to his rights under the Exchange Act, then, the litigant must attempt simultaneous litigation.

Although the relationship of exclusive jurisdiction and collateral estoppel is still the subject of controversy and speculation, ${ }^{30}$ federal courts appear to have settled upon a formula for determining the preclusive effect of prior state determinations on suits brought pursuant to federal securities law: federal courts will accord collateral estoppel effect to state court findings of fact, but not to mixed findings of fact and law. ${ }^{31}$ Since Exchange Act defenses and counterclaims

customer's stock account, see notes 68-69 infra. In those circumstances in which roughly equivalent defenses do exist, an Exchange Act defense may serve as a superior litigation weapon. For example, a common law fraud defense generally requires the showing of a privity relationship, but a $\$ 10(b)$ Exchange Act anti-fraud defense does not. See Cochran v. Channing Corp., 211 F. Supp. 239, $244-45$ (S.D.N.Y. 1962).

28. Will v. Calvert Fire Ins. Co., 437 U.S. 655, 658 (1978).

29. In the context of subsequent litigation, the term collateral estoppel describes the preclusive effect accorded determinations of issues litigated in a former action. See JAMES 8: HAZARD, supra note 1, at 563; Cromwell v. County of Sac, 94 U.S. 351, 353 (1877).

30. See Will v. Calvert Fire Ins. Co., 437 U.S. 655, 668 (Brennan, J., dissenting) ("the preclusive effect of a state-court determination of a claim within the exclusive jurisdiction of the federal courts is an unresolved and difficult issue") (footnote omitted); Calvert Fire Ins. Co. v. American Mutual Reinsurance Co., 600 F.2d 1228, 1236 n.18 (7th Cir. 1979) ("res judicata effect of a prior state court decision ... is an unsettled question"); Colter v. Inter-County Orthopacdic Ass'n, 526 F.2d 537, 542 (3d Cir. 1975) ("Litigation over the judgment preclusion effects of the state court decision ... probably will be as complex as if the federal court had gone ahead with the entire case.") But see Restatement of JUDGMENTS $\$ 71$ (1942) ("Where a court has incidentally determined a matter which it would have had no jurisdiction to determine in an action brought directly to determine it, the judgment is not conclusive in a subsequent action brought to determine the matter directly.") Literal adherence to $\$ 71$ would fully immunize federal courts from the preclusive effect of prior state determinations. Securities case law has not followed the lead of $\$ 71$. See note 31 infra.

The certainty of the first Restatement has been supplanted by an ambiguous approach of the second Restatement linking issue preclusion with "procedural quality" and "jurisdictional allocation." See Restatement (SECOND) of Judgments $\$ 68.1$ (c) (Tentative Draft No. 4, 1977) ("[a] new determination of ... [a previously litigated] issue is warranted by differences in the quality or extensiveness of the procedures followed in the two courts or by factors relating to the allocation of jurisdiction between them"). The second $R e$ statement fails, however, to provide substantive guidelines as to the evaluation of procedural quality or jurisdictional allocation.

31. The origins of this collateral estoppel theory can be traced to the Learned Hand opinion in Lyons v. Westinghouse Elec. Corp., 222 F.2d 184 (2d Cir.), cert. denied, 350 U.S. 825 (1955). Hand broadly stated that "the grant to the district courts of exclusive jurisdiction ... should be taken to imply an immunity of their decisions from any prejudgment elsewhere; at least on occasions ... where the putative estoppel includes the 
arising out of any transaction are likely to involve identical issues, ${ }^{32}$ the possibility exists that state courts hearing Exchange Act defenses will, in effect, adjudicate affirmative Exchange Act claims. ${ }^{33}$ The

whole nexus of facts that makes up the wrong." Id. at 189. However, Hand suggested that state court specific findings of facts, as opposed to mixed findings of fact/law, should be accorded preclusive effect in federal proceedings: "the distinction [exists] between the finding of one of the constituent facts that together make up a claim and the entire congeries of such facts, taken as a unit; an estoppel is good as to the first but not as to the second." Id. at 188 .

The Hand estoppel formula has gained direct or indirect recognition in a number of federal securities decisions. See, e.g., Calvert Fire Ins. Co. v. American Mutual Reinsurance Co., 600 F.2d 1228, 1236 n.18 (7th Cir. 1979) ("fairly settled . . . that state court findings of fact are entitled to collateral estoppel effect in a subsequent federal suit, even if dispositive of the federal question") (emphasis in original); Colter v. Inter-County Orthopaedic Ass'n, 526 F.2d 537, 542 (3d Cir. 1975) (inference that only state-developed historical facts may be estopped; application of law to facts must take place only in federal court); Vernitron Corp. v. Benjamin, 440 F.2d 105, 108 (2d Cir.), cert. denied, 402 U.S. 987 (1971) (doctrine of collateral estoppel would be applied in any instance where state court had determined a factual issue arising in a subsequent federal litigation). Hand's dictum as to the preclusive effect of state court factual findings has been considerably more influential than his dictum suggesting broader federal immunity. But see Will v. Calvert Fire Ins. Co., 437 U.S. 655, 675 (1978) (Brennan, J., dissenting) (citing Hand's broad immunity statement as support for argument against according collateral estoppel effect to state developed historical facts). For analysis of the rationale supporting Brennan's "no estoppel" theory, see note 75 infra.

32. The interrelation between Exchange Act defenses and counterclaims can be demonstrated by a common fact situation: plaintiff alleges in state court that defendant has defaulted on a promissory note tendered in exchange for securities; defendant pleads at the state level that the stock agreement should be rescinded on the basis of $\S 10 \mathrm{~b}-5$ fraud. As a "counterclaim" cannot be raised in state court, this same defendant then enters federal court seeking damages as a $\$ 10 \mathrm{~b}-5$ plaintiff. To a large degree, the federal and state suits require proof of the same facts.

33. While unlikely, it is possible that the doctrine of res judicata or "claim preclusion" may also frustrate the state court defendant's federal assertion of an affirmative Exchange Act claim. The term res judicata refers to the procedural principle by which prior judgment on a given claim precludes relitigation of the same cause of action. See JAMES \& HAZARD, supra note 1 , at 532-33.

Res judicata has been applied to bar federal assertion of Exchange Act rights in cases of parallel plaintiff actions: in two cases, plaintiffs who failed in state securities actions were barred from relitigating the "same cause of action" as a parallel Exchange Act claim in federal court. Connelly v. Balkwill, 174 F. Supp. 49 (N.D. Ohio 1959), aff'd, 279 F.2d 685 (6th Cir. 1960) (per curiam) (plaintiff's federal $\S 10 \mathrm{~b}$ suit barred as result of state judgment for defendant on common law fraud claim; court held in alternative that principle of collateral estoppel precluded relitigation); Kaufman v. Shoenberg, 154 F. Supp. 64 (D. Del. 1954) (on identity of actions theory, adverse judgment by state court on state proxy law suit barred plaintiff's $\$ 14$ Exchange Act suit). Connelly has not been followed, see, e.g., Clark v. Watchie, 513 F.2d 994, $997-98$ (9th Cir.), cert. denied, 423 U.S. 841 (1975); Klein v. Walston \& Co., 432 F.2d 936, 937 (2d Cir. 1970) (per curiam); cf. Will v. Calvert Fire Ins. Co., 437 U.S. 655, 674 (1978) (Brennan, J., dissenting) ("For myself, I confess to serious doubt that it is ever appropriate to accord res judicata effect to a state court determination of a claim over which the federal courts have exclusive jurisdiction; for surely state court determinations should not disable federal courts from ruling de novo on purely legal questions surrounding such federal claims.") However, res judicata may be applicable to cases in which state court approval of Exchange Act settlements is the subject of later federal litigation. See Boothe v. Baker Indus., Inc., 262 F. Supp. 168 (D. Del. 1966); Dembitzer v. First Republic Corp., [1964-1966 Transfer Binder] FED. SEC. L. REP. (CCH) ๆ 91,566 (S.D.N.Y. 1965). 
fact that federal courts accord preclusive effect to state court findings of fact is not inherently prejudicial to the successful prosecution of Exchange Act claims. ${ }^{34}$ But in many states, discovery rules are less liberal ${ }^{35}$ than the federal rules. ${ }^{36}$ Limitations on the scope of dis-

34. According preclusive effect to state court determinations in jurisdictions that have adopted procedural rules identical with or very similar to the Federal Rules of Civil Procedure would not necessarily prejudice Exchange Act rights. As a result of the similarity in such forums of federal and state discovery rules, state factual development will have been assisted by the very procedural safeguards available in federal court. A number of jurisdictions have adopted either the Federal Rules or very similar analogues: Alabama, Alaska, Arizona, Colorado, Delaware, District of Columbia, Hawaii, Idaho, Kentucky, Maryland, Minnesota, Nevada, New Jersey, New Mexico, North Dakota, Puerto Rico, Tennessee, Utah, Virgin Islands, West Virginia, Wyoming. See 1 W. BarroN \& A. Holtzoff, Federal Practice and Procedure $\$ \$ 9.0-53$ (1960 \& Supp. 1975). Through partial statutory reform or court rule adoption, other states have undertaken efforts to track the discovery provisions of the Federal Rules: Arkansas (ARK. STAт. ANN. $\$ \S 28.348$ to 359 (1962 \& Supp. 1975)); California (CAL. CIv. Proc. CODE $\$ \S 2016-2034$ (West 1965 \& Supp. 1979)); Florida (FrA. CT. R.C.P. $\$ \$ 1.280-.380$ ); Louisiana (LA. CodE Civ. Pro. ANN. art. 1421-1473 (West 1960 \& Supp. 1978)); Maine (ME. CT. C.P.R. $\$ \S 26.37$ ); Missouri (Mo. CT. C.P.R. 56-61); South Dakota (S.D. Comp. LAws ANN. $\$ \$ 15-6-26$ to 37 (1967 \& Supp. 1978)); Vermont (VT. CT. C.P.R. $\$ \S 26-37$ ); Washington (WASH. CT. C.P.R. $\$ \S 26-37$ ).

35. The prejudicial impact on Exchange Act rights resulting from the interrelation of collateral estoppel and restrictive state procedure has been noted by a number of federal cases. See, e.g., Will v. Calvert Fire Ins. Co., 437 U.S. 655, 675 (1978) (Brennan, J., dissenting) ("It is at least arguable that in creating and defining a particular federal claim, Congress assumed that the claim would be litigated only in the context of federal-court procedure-a fair assumption when the claim is within exclusive federal jurisdiction ... Congress may have thought the liberal federal discovery procedures crucial to the proper determination of the factual disputes underlying the federal claim."); Weisfeld v. Spartans Indus., Inc., 58 F.R.D. 570, 577 (S.D.N.Y. 1972) (stay of parallel federal action denied because "[d]iscovery under the Federal Rules of Civil Procedure is more liberal than discovery under the New York Civil Practice Law and Rules").

Recent law review commentaries have also recognized the potential for prejudicial adjudication of a state defendant's affirmative Exchange Act claims. See, e.g., Note, The Collateral Estoppel Effect of Prior State Court Findings in Cases Within Exclusive Federal Jurisdiction, 91 HARv. L. REv. 1281, 1282 (1978) [hereinafter cited as Collateral Estoppe].

The civil procedure codes of a number of states are, in varying degrees, less liberal than the discovery mandates of the federal rules, see FED. R. CIv. P. 26-37. These jurisdictions include: Connecticut, Georgia, Illinois, Indiana, Iowa, Kansas, Massachusetts, Michigan, Mississippi, Montana, Nebraska, New Hampshire, New York, North Carolina, Ohio, Oklahoma, Oregon, Pennsylvania, Rhode Island, South Carolina, Texas, Virginia, and Wisconsin. See I W. Barron \& A. Holtzoff, Frderal Practice and Procedure $\$ \$ 9.0-.53$ (1960 \&: Supp. 1975).

36. An important forum for securities cases, New York, illustrates the disparity between liberal federal discovery provisions and restrictive state rules. In 1961, the New York legislature rejected a liberal relevancy standard for discovery patterned after Federal Rule 26, see J. Weinstein, H. Korn \& A. Miller, New York CiviL Practice I 3101.02 (1978) [hereinafter cited as WEINSTEIN \& KoRN], and incorporated a more cautious "material and necessary" standard into the New York disclosure rules. See N.Y. Giv. Prac. LAw $\$ 3101(a)$
(McKinney 1963 \&: Supp. 1978-79).

The limited approach of the New York rule has substantially curtailed discovery in securities suits. See, e.g., Matter of Baron v. Royal Paper Corp., 36 A.D.2d 112, 114, 318 N.Y.S.2d 327, 329 (1971) (in suit concerning sale of close corporation stock pursuant to agreement stipulating accountant's share value report as final, discovery regarding corporate books not permitted); Pearson v. Rosenberg, 22 A.D.2d 225, 228, 254 N.Y.S.2d 690, 693 (1964) (Breitel, J.) (derivative suit) ("examination should proceed only with 
covery may be detrimental to the counterclaiming litigant due to the factual complexity of many securities cases. ${ }^{37}$ In particular, proof of the key element of a section 10(b) Exchange Act defense-scienter ${ }^{38}-$ may be difficult without broad discovery. ${ }^{39}$ Restrictions on access to corporate documents or officials could thus effectively frustrate assertion of an Exchange Act right.

If the state court defendant elects to file a parallel federal suit contemporaneous with his state court Exchange Act defense in order to avoid the possible prejudicial effects of collateral estoppel, he may

respect to specified matters and not broadly under the pleadings"). This limited discovery approach may impair a state defendant's ability to prove Exchange Act claims (such as $\S 10(\mathrm{~b})$ fraud) due to the often critical need for examination of masses of corporate records. See, e.g., State v. DeGroot, 60 Misc. 2d 816, 817, 304 N.Y.S.2d 143, 144 (Sup. Ct. 1969) ("[court] cannot permit a roving examination of a great mass of documents without proof that all that is sought is relevant and necessary").

Beyond the "materiality" standard, discovery in New York also is constrained by technical requirements absent from federal discovery. Depositions of nonparties may be taken on a conditional basis only. See N.Y. Civ. Prac. LAw \$ 3101(a) (McKinney 1963 \& Supp. 1978-79). Because depositions of corporate-related accountants and attorneys may be crucial to a securities fraud defense and affirmative claim, Exchange Act rights may be seriously jeopardized by the New York civil practice distinction between parties and nonparties. Whereas Federal Rule 31(a) provides for the taking of depositions on written questions without limitation, New York rules permit such depositions to be taken only when "the examining party and the deponent so stipulate or when the testimony is to be taken without the state." N.X. Civ. Prac. Law $\$ 3108$ (McKinney 1963 \& Supp. 1978-79). As written depositions are less costly than oral interrogation, see WEINSTEIN \& KoRN, supra, at 3108.03 , the New York rules may be utilized to deprive a financially pressed Exchange Act defendant of an inexpensive discovery vehicle.

Finally, New York rules also lack important procedural advances recently incorporated into the federal rules. The 1970 amendments to the federal rules require supplementation of interrogatory responses on the basis of subsequent information, see FED. R. Civ. P. 26(e); the New York code fails to impose on the respondent this continuing duty, see N.Y. CIv. Prac. LAw $\$ 3134$ (McKinney 1963 \& Supp. 1978-79); WeInstein \& KorN, supra, at 3134.07. Consequently, newly uncovered corporate documents may be omitted from state trial evidence without sanction.

In response to the restrictive nature of New York discovery, "[o]ften suits are brought in federal court solely to take advantage of the broader disclosure available there." WEINSTEIN \& KORN, supra, at 1 3101.14; see Weisfeld v. Spartans Indus., Inc., 58 F.R.D. 570 (S.D.N.Y. 1972).

37. See WeInsteIn \& KoRN, supra note 36 , at 9101.14 ; Weinstein \& Bergman, New York Procedures to Obtain Information in Civil Litigation, 32 N.Y.U. L. REv. 1066, 108081 (1957).

38. See Ernst \& Ernst v. Hochfelder, 425 U.S. 185, 193 (1976) (proof of scienter required in private cause of action under Rule $10 \mathrm{~b}-5)$.

39. See FED. R. Civ. P. 26(b)(1); notes 35-36 supra.

It has also been argued that effective adjudication of Exchange Act affirmative claims in state court would deprive the litigant of his federal right under the Seventh Amendment to trial by jury. See Lecor v. District Court, 502 F.2d 104, 105 (9th Cir. 1974); Wellington Computer Graphics, Inc. v. Modell, 315 F. Supp. 24, 27 (S.D.N.Y. 1970). (The jury trial argument, however, may not be of great significance. In complicated securities cases, the advantage or protection of jury as opposed to bench trial is of speculative value. Cf. In re U.S. Financial Securities Litigation, 75 F.R.D. 702 (S.D. Cal. 1977); In re Boise Cascade Securities Litigation, 420 F. Supp. 99 (W.D. Wash. 1976). 
encounter serious obstacles. To avoid duplicative litigation, the federal court can, upon motion, stay its consideration in deference to a previously initiated state court action, ${ }^{40}$ postponing federal adjudication until such time as the state court has established its specific findings of fact. Should the district court grant a stay, the simultaneous litigation strategy will then fail to shield the litigant from the unfavorable effects of collateral estoppel. ${ }^{41}$ Even if successful, the dual suit strategy, by requiring contemporaneous defense in one suit and prosecution in another, dramatically increases litigation costs for the state court defendant.

\section{B. Judicial Inefficiency}

By forcing state defendants to litigate simultaneously in two courts to protect their Exchange Act rights, the disparate treatment of defenses and counterclaims undermines the values of judicial economy served by the compulsory counterclaim rule. ${ }^{42}$

In a state law suit based on a contractual obligation, a common law fraud counterclaim would arise out of the same transaction as the plaintiff's action and therefore would be a compulsory counterclaim; if the defendant failed to raise the counterclaim at the same time and in the same forum as the plaintiff's action, the litigant would be barred from later assertion of the fraud claim. But an analogous

40. Will v. Calvert Fire Ins. Co., 437 U.S. 655, 664 (1978) (decision to defer to state court proceedings "largely committed to the discretion of the District Court").

In addition to the district court in Will, a number of other courts have granted motions to stay parallel federal proceedings. See, e.g., Shareholders Management Co. v. Gregory, 449 F.2d 326, 327 (9th Cir. 1971) (per curiam) (federal action should not be dismissed but stayed); Klein v. Walston \& Co., 432 F.2d 936, 937 (2d Cir. 1970) (per curiam) (approving of district court stay). Other courts have denied motions to stay contemporaneous federal actions. See, e.g., Movielab, Inc. v. Berkey Photo, Inc., 321 F. Supp. 806, 811 (S.D.N.Y. 1970), aff'd, 452 F.2d 662 (2d Cir. 1971); Lewis v. Marine Midland Grace Trust Co., 63 F.R.D. 39, 53 (S.D.N.Y. 1973); Weisfeld v. Spartans Indus., Inc., 58 F.R.D. 570, 581 (S.D.N.Y. 1972).

41. Alternatively, a litigant may seek to immunize the federal action through a federal injunction of the state proceeding. Such a litigation strategy would be based on one of the enumerated exceptions to the federal anti-injunction statute, 28 U.S.C. $\$ 2283$ (1976). Litigants have argued that in order to prevent the intrusion of state determined facts, a restraint of the state action was authorized as "necessary in aid" of district court Exchange Act exclusive jurisdiction. Despite the clear possibility that the federal court adjudication of affirmative Exchange Act claims may be effectively precluded by state court defense consideration, federal courts have refused to enjoin parallel state actions. See, e.g., McGough v. First Arlington Nat'l Bank, 519 F.2d 552, 555 (7th Cir. 1975); Vernitron Corp. v. Benjamin, 440 F.2d 105, 108 (2d Cir.), cert. denied, 402 U.S. 987 (1971).

42. Under the compulsory counterclaim rule, all defendant claims arising out of the transaction or occurrence subject of plaintiff's action must be asserted at the same time and in the same forum as the plaintiff's suit. See FEn. R. Civ. P. 13(a); JAMES \& HAzARD, supra note 1 , at 490 . 
Exchange Act counterclaim cannot be pleaded in the state court action and can only be adjudicated in a federal forum. In contrast to the compulsory counterclaim rule that serves to consolidate all relevant claims within one forum, ${ }^{43}$ the rule requiring federal court adjudication of Exchange Act counterclaims fosters judicial inefficiency by compelling federal and state courts to adjudicate essentially identical claims and issues. ${ }^{44}$

\section{Toward a New Jurisdictional Scheme: Inadequacies of Proposed Alternatives}

The breakdown in exclusivity has resulted in a litigation pattern detrimental to both Exchange Act claimants and the value of judicial economy. Two alternatives immediately present themselves: restricting the jurisdiction of the states, or expanding the jurisdiction of the states. But neither of these choices, in isolation, can adequately resolve the tension generated by the incomplete nature of exclusive jurisdiction and the emergence of the transactional case.

\section{A. Reduced State Court Jurisdiction: Federal Question Removal}

Restricting the jurisdiction of the state courts would both prevent the intrusion of state determined facts and guarantee the unitary adjudication of federal and state claims. The primary method that has been suggested for achieving this objective is federal question removal on the basis of an Exchange Act defense or counterclaim. ${ }^{45}$

43. See Wright, Estoppel by Rule: The Compulsory Counterclaim under Modern Pleading, 38 MINN. L. REv. 423, 465 (1954) (compulsory counterclaim rule is "an important part of the movement to end a multiplicity of litigation, and thus [is] in the interest of both litigants and the public").

44. See Weiner v. Shearson, Hammill \& Co., 521 F.2d 817, 820 (9th Cir. 1975) (dual suit litigation results in waste of judicial resources, unnecessary burden on overcrowded dockets, and undue burden on litigants).

In 1977, the number of cases filed in both the courts of appeals and the district courts reached record proportions. See [1977] AnNual Report of the Director, Administrative OfFice of THE United States Courts 2 [hereinafter cited as 1977 ANnual Report]. The overcrowding of federal dockets has resulted in a judicial crisis termed by one study as "the paradox of courts working furiously and litigants waiting endlessly." U.S. DEP'T OF Justice, The Needs of the Federal Courts: Report of the Department of Justice Committee on Revision of the Federal Judicial SYSTEM 3 (1977).

45. See American Law Institute, Study of the Division of Jurispiction Between State and Federal Courts 187-207 (1969) [hereinafrer cited as ALI Study]; Currie, The Federal Courts and the American Law Institule II, 36 U. CHr. L. Rev. 268, 271-76 (1969); Moore, Problems of the Federal Judiciary, 35 F.R.D. 305, 316 (1964).

Under current judicial and statutory guidelines, a state defendant cannot remove the action to federal court by pleading either a federal defense or a federal counterclaim. See Tennessee v. Union and Planters' Bank, 152 U.S. 454 (1894); 28 U.S.C. \$ 1441 (1976). 
As outlined by the American Law Institute [ALI], a state defendant pleading a federal defense or counterclaim would be allowed to remove the entire action to federal court, if either the defense is potentially dispositive of the action and the amount in controversy exceeds $\$ 10,000$, or the counterclaim is compulsory ${ }^{40}$ under state law and asserts a substantial federal right. ${ }^{47}$

The ALI proposal seems to be responsive to many of the problems that plague the current jurisdictional scheme. Federal question removal would ensure that Exchange Act claims were adjudicated in a federal forum. Because Exchange Act claimants would be protected from the prejudicial effects of collateral estoppel, there would be no incentive for these litigants to appear in more than one action. In addition, judicial economy would be served by the resolution of the dispute in one forum.

Although superior to the current pattern of prejudicial and inefficient litigation, the ALI proposal is subject to certain serious infirmities. Because a defendant might perceive a tactical advantage in forcing removal, ${ }^{48}$ a lenient federal question removal standard might clog already overburdened federal courts with frivolous defenses and counterclaims that would waste judicial resources. ${ }^{49}$ The ALI proposal seems to anticipate this problem by establishing standards as barriers to purely tactical removal motions. ${ }^{50}$ But the ALI "dis-

The current removal restrictions have been justified on the grounds that removal is inappropriate "when litigants rely on federal rights to furnish them a shield but not a sword." Wechsler, Federal Jurisdiction and the Revision of the Judicial Code, 13 LAw \& Contemp. Prob. 216, 234 (1948).

46. See note 42 supra.

47. See ALI STUDY, supra note 45, \$ 1312(a)(2), (3), at 25-26. Under ALI $\$ 1312(\mathrm{~b})$, a number of federal acts are specifically exempted from the provision for federal defense and counterclaim removal. Id. at 26-27. The Exchange Act is not included among the enumerated acts. For a discussion of the ALI removal proposals, see Currie, supra note 45, at 269-76.

48. As conceded by the ALI draft, an ingenious lawyer might utilize federal defense and counterclaim removal as a device to harass both plaintiff and court. See ALI STuDY, supra note 45 , at 199-200. Such deliberate harassment might result in an unwarranted settlement advantageous to the state defendant.

49. Many judges fear that further additions to federal jurisdiction will seriously impair the capacity of federal courts. Chief Judge Phillips of the Sixth Circuit has been particularly outspoken: "The federal courts are confronted with a crisis of such proportions that their dockets threaten to become unmanageable. This situation is attributable to at least three interrelated elements: a steadily rising caseload, expanded federal jurisdiction, and an insufficient number of judges to meet these demands." Phillips, The Expansion of Federal Jurisdiction and the Crisis in the Courts, 31 VAND. L. Rev. 17, 17 (1978). See H. Friendly, Federai. Jurisdiction: A General View 124 (1973) (questioning advisability of permitting federal defense removal "when the federal courts are under such severe pressure").

50. See ALI SruDY, supra note 45, § 1312(a)(2), (3), at 25-26 (barriers include amount in controversy, "dispositive" defense, and "compulsory" counterclaim standards). 
positive," "substantial," and "compulsory" tests for removal are themselves likely to generate considerable, protracted litigation, ${ }^{, 1}$ which would only be increased by the amount-in-controversy requirement. ${ }^{52}$ It is likely that the ALI felt compelled to impose these obstacles to total removal in anticipation of congressional displeasure with any proposal increasing the federal court caseload. ${ }^{53}$ However, by opting for something less than complete federal removal, the ALI sacrificed the efficiency of a rule of exclusive jurisdiction.

Moreover, the displacement of the state role resulting from federal question removal contradicts the principles of federalism embodied in the balance between the state and federal judicial systems. ${ }^{54}$ In the attempt to preserve the nexus between federal right and federal procedure, the ALI proposal fails to utilize the societal resources traditionally concentrated in the state adjudication of state law claims..$^{55}$

\section{B. Expanded State Court Jurisdiction: Concurrent Jurisdiction}

The duplicative litigation pattern fostered by the incomplete nature of exclusive jurisdiction might also be eliminated by the expansion of state court jurisdiction. In a separate proposal, the ALI has suggested that section 27 of the Exchange Act be amended to allow state court concurrent jurisdiction. ${ }^{56}$ Following the ALI amendment,

51. Professor Currie finds the "compulsory counterclaim" test to be a particularly ill-advised threshold requirement. See Currie, supra note 45 , at 275 (test requires "burdensome inquiry respecting state compulsory counterclaim rules"). The "dispositive" test may lend itself to varying judicial interpretations. Additionally, the ALI draft fails to offer guidelines as to what would be considered a "substantial" or "insubstantial" Exchange Act counterclaim.

52. See ALI STUdY, supra note $45, \$ 1312(a)(2)$, at 25 . Removal motions will be subject to the challenge that the amount-in-controversy requirement has not been satisfied.

53. In recent years, congressional legislation to modify or abandon federal diversity jurisdiction has been regularly introduced. While all such attempts, including the most recent, H.R. 9622, 95th Cong., 2d Sess. (1978), have failed, diversity jurisdiction continues to be subject to sharp attack. See, e.g., Phillips, supra note 49, at 23-26. A proposal for state court adjudication of "exclusive" counterclaims might gain wider congressional acceptance as it would reduce rather than increase federal caseloads.

54. The Burger Court has indicated its intention to restore the federalist balance through increased deference to state court adjudications. See, e.g., Wainwright v. Sykes, 433 U.S. 72 (1977); Stone v. Powell, 428 U.S. 465 (1976).

55. See Wainwright v. Sykes, 433 U.S. 72, 90 (1977).

56. ALI STUDY, supra note 45 , at 78-79, 183, 413. The draft of the ALI Proposed Federal Securities Code would also authorize state courts to exercise concurrent jurisdiction over civil securities actions. American Law Institute, Federal Securities Code, $\$ 1822$, at 701 (1978) [hereinafter cited as ALI CODE]. The ALI proposal for concurrent jurisdiction has been cited in circuit opinions. Calvert Fire Ins. Co. v. American Mutual Reinsurance Co., 600 F.2d 1228, 1235 n.16 (7th Cir. 1979); Colter v. Inter-County Orthopaedic Ass'n, 526 F.2d 537, 542 n.1 (3d Cir. 1975).

The Exchange Act is the only federal securities act mandating exclusive jurisdiction. All other federal securities legislation provides for concurrent jurisdiction. See, e.g., 
a state court could entertain jurisdiction over plaintiff Exchange Act claims as well as defendant Exchange Act defenses and counterclaims. One advantage of this proposal is that it would clearly eliminate any controversy about the extent of state court jurisdiction under the Exchange Act. ${ }^{57}$ As a result, judicial economy would be improved by the unitary adjudication of the Exchange Act defense and counterclaim. But before the states can share full responsibility for adjudicating Exchange Act claims, the traditional arguments supporting exclusive federal jurisdiction must be overcome. ${ }^{58}$

Securitics Act of 1933, $\S 22(a)$, 15 U.S.C. $\$ 77 v(a)$ (1976); Investment Company Act of $1940, \S 44,15$ U.S.C. $\$ 80 \mathrm{a}-43$ (1976); Investment Advisers Act of 1940, $\$ 214$, 15 U.S.C. $\$ 80 \mathrm{~b}-14$ (1976). Cf. Loss, supra note 10 , at 1275 ("the dubious advantages of exclusive federal juriscliction do not sufficiently outweigh the complexities it has created . . . and the statute [\$27] should be amended to conform to the concurrent-jurisdiction pattern of all the other SEC acts").

57. See generally note 10 supra (discussing extent of state court jurisdiction of Exchange Act defenses).

58. For caselaw and commentaries discussing the traditional arguments supporting exclusive federal jurisdiction, see, e.g., Will v. Calvert Fire Ins. Co., 437 U.S. 655, 670-72 (1978) (Brennan, J., dissenting); American Distilling Co. v. Brown, 184 Misc. 431, 433, 51 N.Y.S.2d 614, 616 (Sup. Ct. 1944), aff'd mem., 269 App. Div. 763, 54 N.Y.S.2d 855 (1st Dept.), aff'd, 295 N.Y. 36, 64 N.E.2d 347 (1945); ALI SruDY, supra note 45, at 164-68; Currie, supra note 45 , at 268 .

The traditional arguments supporting exclusive federal jurisdiction fail to find expression in the legislative history of the Exchange Act. At best, fragments of the legislative history suggest that the congressional grant of Exchange Act exclusive jurisdiction was largely the result of "pure happenstance." ALI STUDY, supra note 45, at 183. The early versions of the House bill failed to indicate specifically whether jurisdiction was to be exclusive or concurrent. See H.R. 7852, 73d Cong., 2d Sess., reprinted in Stock Exchange Regulation: Hearing on H.R. $7 \$ 52$ and H.R. $\$ 720$ Before the Comm. on Interstate and Foreign Commerce, 73rd Cong., 2d Sess. 14 (1934) (bill is at 1-15). An intermediate version explicitly mandated concurrent Exchange Act jurisdiction. See H.R. 7924, 73rd Cong., 2d Sess., $\$ \mathfrak{G}(a), 78$ CoNG. REC. 8029 (1934) (bill is at 8028-8030). The bill finally reported out of the Committee on Interstate and Foreign Commerce simply provided that "[t]he district courts of the United States ... shall have jurisdiction of violations of this title ..." H.R. 9323, 73d Cong., $2 d$ Sess., $\$ 26$ (1934), reprinted in 10 Legislative History of the Securitres ACt of 1933 and Securiries Exchange ACt of 1934, Item 30 at 52 (1973) [hereinafter cited as LEGisLATive History]. With virtually no floor debate, the bill was successfully amended to authorize exclusive federal jurisdiction. See 78 Cong. Rec. 8099 (1934) (amendment offered by Congressman Rayburn) ("Mr. Chairman, I have only this to say-that we thought the bill as drawn meant exclusive, but in order that it may be entirely clear we offer this amendment"); H.R. 9323, 73rd Cong., 2d Sess., $\$ 26$ (1934) (bill passed by House), reprinted in 10 Legislative History, Item 31 at 52 . In the Senate, an early draft of the bill mandated concurrent jurisdiction. S. 2642, 73rd Cong., 2d Sess., § 8(a) (1934), reprinted in 11 Legislative HistoRY, Item 33 at 11 . A later Senate draft eliminated the explicit concurrent feature. See S. 2693, 73rd Cong., 2d Sess., \$ 25(a) (1934), 78 Cong. Rec. 2265-2270 (1934) (\$ 25(a) at 2269-2270). This ambiguous approach was incorporated into the bill actually passed by the Senate. See S. 3420, 73rd Cong., 2d Sess., $\$ 26(a)$ (1934), reprinted in 11 LegisLative History, Item 27 at 50.

The disparity between the "exclusive" House bill and the ambiguous Senate draft was briefly acknowledged in the Senate debate on the bill. See 78 Conc. Rec. 8571 (1934) (remarks of Senators Byrnes, Fletcher, and Steiwer). The matter was left for Conference Committee determination. Id. This apparently minor dispute was resolved by the Con- 
Proponents of exclusive jurisdiction advance four principal claims in support of their position. First, they argue that uniform interpretation of the Exchange Act is promoted by denying jurisdiction to state courts. ${ }^{59}$ Although the uniformity argument might support reduced state responsibility, it fails to distinguish between what exists currently and full concurrent juriscliction: present law already tolerates serious state intrusions into the uniform, federal adjudication of the Exchange Act. ${ }^{00}$ The interpretative uniformity argument

ference Committee in favor of the House text. See 78 Conc. Rec. 9939 (1934); S. Doc. No. 185, 73rd Cong., 2d Sess. (1934); H. ReP. No. 1838, 73rd Cong., 2d Sess. (1934). Neither Senate nor House document indicates any reason for the election of Exchange Act exclusive jurisdiction.

59. It has been argued that state court interpretation of federal rights raised as counterclaims would add the views of the 50 state courts to whatever interpretative disparities exist among the 11 federal circuits. See Will v. Calvert Fire Ins. Co., 437 U.S. 655, 675-76, (1978) (Brennan, J., dissenting). In his opinion, Justice Brennan extends the uniformity argument as support for a federal no-estoppel rule: "If res judicata effect is accorded the prior state court judgment, the exclusive jurisdiction given the federal courts over 1934 Act claims would be effectively thwarted, and the policy of uniform and effective federal administration and interpretation of the 1934 Act frustrated." Id. As support for the denial of state court jurisdiction, it has been asserted that the practical limits of Supreme Court review of state decisions prevent resolution of Exchange Act interpretative conflicts among courts of different states or between the courts of the federal and state systems. Indeed, the number of state court appeals the Supreme Court may review pursuant to 28 U.S.C. $\$ 1257$ (1976) is greatly limited by the sheer number of certiorari petitions filed. See $\mathbf{P}$. Brest, Processes of Constitutional Decisionmaking 76 (1975) ("Court now grants less than 5 percent of the petitions filed"); Federal Judicial Center, Report of the Study Group on the Caseload of the Supreae Court 3-4 (1972) (percentage of petitions granted has dropped from $17.5 \%$ in 1941 to $5.8 \%$ in 1971 ).

60. In particular, a state court may resolve the facts and law pertaining to an Exchange Act defense. See pp. 97-98 supra.

State court adjudication of Exchange Act defenses is not the only significant intrusion into exclusive federal jurisdiction. In a number of areas, state proceedings may have an important bearing on federal Exchange Act claims. State court specific findings of fact concerning an Exchange Act defense or state law counterclaims may be accorded significant collateral estoppel effect in federal actions concerning related Exchange Act claims. See pp. 101-05 supra. Furthermore, state court approval of settlements releasing Exchange Act claims, which involves consideration of both facts and Exchange Act law, will be recognized in federal courts despite the $\$ 27$ grant of exclusive jurisdiction. See, e.g., Boothe v. Baker Indus., Inc., 262 F. Supp. 168 (D. Del. 1966) (Exchange Act $\$ \$ 10 \mathrm{~b}, 14 \mathrm{a}$ suit barred by state court adoption of referee's recommendation to approve settlement); Dembitzer v. First Repub. Corp., [1964-1966 Transfer Binder] FEd. SEc. L. REP. (CCH) I] 91,566 (S.D.N.Y. 1965) (state court settlement of breach of fiduciary duty and self-dealing claims held to bar $\$ 10 \mathrm{~b}$ action); cf. Abramson v. Pennwood Inv. Corp., 392 F.2d 759, 762 (2d Cir. 1968 ) (state court has power to approve release of $\S 10 \mathrm{~b}$ claim as a condition of settlement; state approval of release, not principle of res judicata, precludes federal relitigation).

The uniformity argument may also be challenged on the grounds that interpretative conflicts among the federal circuits are often not resolved due to the low number of cases granted certiorari by the Supreme Court. See Federal Judicial Center, supra note 59, at 1-9; Note, Exclusive Jurisdiction of the Federal Courts in Private Civil Actions, 70 HARv. L. REv. 509, 511 (1957). But see H. FRIENDLY, supra note 49, at 52 (“[m]y own impression is that ... resolved and unresolved conflicts in any [Supreme Court] term are relatively few.") (footnote omitted). As state court Exchange Act counterclaim jurisdiction would only marginally enlarge the extent of state court involvement, it is unlikely that state counterclaim consideration would measurably add to existing judicial conflict. 
is further strained by the fact that state courts are free to award equitable relief on the basis of an Exchange Act defense and are prohibited only from ordering affirmative relief or damages. ${ }^{61}$ When an Exchange Act defense is raised to a state law contract action, equitable relief rescinding the agreement may be of greater significance to the litigants than a monetary arvard..$^{62}$ Additionally, deciding issues surrounding a plea for equitable relief may require as extensive an interpretation of federal securities law as would analyzing a counterclaim.

Second, it is generally assumed that federal judges possess greater expertise than state jurists in adjudicating federal law. ${ }^{63}$ However, this concern over the competence of state judges to rule on federal counterclaims seems less compelling today than when the Exchange Act was adopted. The assumption that state judges are unable to grapple with securities law originated in an era in which securities legislation was relatively foreign to state systems. Today, state courts are much more familiar with securities litigation as a result of the adoption of the Uniform Securities Act [USA] in a majority of states. ${ }^{64}$

61. A similarly tenuous distinction exists at the level of defenses, which can be adjudicated by a state court, and counterclaims, which cannot. See, e.g., Susquehanna S.S. Co. v. Andersen \& Co., 239 N.Y. 285, 292, 146 N.E. 38I, 383 (1925) (Cardozo, J.) ("A discussion of ... subtlety has centred upon the distinction between ... counterclaims and ... defenses"). See generally 3 Moore's Federal Practice I 13.09 (2d ed. 1979 \& Supp. 1978-79).

As a function of the difficulties in distinguishing counterclaims from affirmative defenses, the draftsmen of the Federal Rules adopted a highly flexible standard for the treatment of counterclaims and defenses: "When a party has mistakenly designated a defense as a counterclaim or a counterclaim as a defense, the court on terms, if justice so requires, shall treat the pleading as if there had been a proper designation." FED. R. Crv. P. 8(c). For judicial construction of the Rule 8(c) permissive standard, see 2A MOORE's Federal Practice [f 8.27[3] (2d ed. 1979 \& Supp. 1978-79).

62. Rescission of a promissory note agreement is central to any deficiency defense. If equitable relief is granted, the defendant will have been largely compensated for the plaintiff's Exchange Act violation. Additional affirmative claims for lost transaction or opportunity costs, while significant, may suffer from problems of proof. Further, the value of the rescissionary remedy is increased in light of the statutory, see $\S 28(\mathrm{a}), 15$ U.S.C. $\$ 78 \mathrm{bb}(\mathrm{a})$ (1976), and judicial rejection of claims for Exchange Act punitive damages, see Byrnes v. Faulkner, Dawkins \& Sullivan, 550 F.2d 1303 (3d Cir. 1977); Straub v. Vaisman \& Co., Inc., 540 F.2d 591 (3d Cir. 1976). But see Hall v. Security Planning Services, Inc., 419 F. Supp. 405, 408 (D. Ariz. 1976) ('defendants' course of conduct . . . so filled with knowing and wilful fraud" as to warrant award of punitive damages). Punitive damages may be obtained in federal court on the basis of pendent state law claims. See Young v. Taylor, 466 F.2d 1329 (10th Cir. 1972). See generally R. JENnings \& H. M.arsh, Securities Regulation 1085-88 (1977).

63. See ALI Study, supra note 45, at 164-65; Note, Collateral Estoppel, supra note 35, at 1282; Note, Nonfederal Proceedings, supra note 10, at 961.

64. Drafted by Louis Loss and Edward M. Cowett, the Uniform Securities Act [USA] was approved by the National Conference of Commissioners on Uniform State Laws on August 25, 1956. Since that time, thirty-two states as well as the District of Columbia and Puerto Rico have codified the Act. See 7A Uniform Laws Annotated 56I-62 (1978) \& 19 (Supp. 1979). 
Because the USA tracks much of the language and many of the standards of the federal securities laws, ${ }^{65}$ cases arising under the USA have provided state court judges with the opportunity to hear and decide securities cases analogous in many respects to federal actions. ${ }^{66}$ Moreover, these is no compelling empirical evidence underlying the incompetency generalization. ${ }^{67}$ An examination of margin requirement ${ }^{68}$ litigation, the subject of a significant number of Exchange Act defenses in state courts, is instructive. In state court cases in which violations of

65. In particular, the anti-fraud provisions of the USA and Exchange Act are virtually identical. Section 101 of the USA provides:

$\$ 101$. [Sales and Purchases]

It is unlawful for any person, in connection with the offer, sale, or purchase of any security, directly or indirectly

(1) to employ any device, scheme, or artifice to defraud,

(2) to make any untrue statement of a material fact or to omit to state a material fact necessary in order to make the statements made, in the light of the circumstances under which they are made, not misleading, or

(3) to engage in any act, practice, or course of business which operates or would operate as a fraud or deceit upon any person.

Compare the above language with that of Rule X-10B-5, 17 C.F.R. $\$ 240.10 \mathrm{~b}-5$ :

Employment of manipulative and deceptive devices.

It shall be unlawful for any person, directly or indirectly, by the use of any means or instrumentality of interstate commerce, or of the mails or of any facility of any national securities exchange,

(a) To employ any device, scheme, or artifice to defraud,

(b) To make any untrue statement of a material fact or to omit to state a material fact necessary in order to make the statements made, in the light of the circumstances under which they were made, not misleading, or

(c) To engage in any act, practice, or course of business which operates or would operate as a fraud or deceit upon any person, in connection with the purchase or sale of any security.

66. State courts have addressed claims similar to those under Exchange Act $\$ 10(\mathrm{~b})$ in suits for violation of USA $\$ 101$. See, e.g., B \& T Distributs. Inc. v. Riehle, 366 N.E.2d 178,179 (Ind. 1977) (evidence sustained trial court judgment that alleged false representations did not violate Indiana Securities Act antifraud provision); Berki v. Reynolds Secs., Inc., 277 Or. 335, 341, 560 P.2d 282, 286 (1977) (alleged manipulation of plaintiff's stock account did not violate antifraud section of Oregon Securities Act). Cases analogous to Exchange Act $\$ 10(\mathrm{~b})$ civil actions have also arisen under the USA $\$ 410$ provision for civil liability in cases of false representations or material omissions. See, e.g., Shultz v. Rector-Phillips-Morse, Inc., 552 S.W.2d 4 (Ark. 1977); City of Owensboro v. First U.S. Corp., 534 S.W.2d 789 (Ky. 1975).

67. The belief that state courts are incompetent to adjudicate Exchange Act claims appears to be derived largely from the fact that Congress in drafting $\$ 27$ affirmatively withdrew jurisdiction from the state system, see note 58 supra. One commentator has suggested, however, that the congressional grant to the states of concurrent jurisdiction under the 1933 Act, 15 U.S.C. $\$ 77 v($ a) (1976), " is . . . evidence that [the Congress] did not lack confidence in the competency of state courts to handle securities matters." Note, Implied Rights Under the Securities Exchange Act of 1934-Federal Jurisdiction-Exclusive or Concurrent?, 21 CASE W. RES. L. REv. 93, 97 (1969) (footnote omitted) [hereinafter cited as Implied Rights].

68. 15 U.S.C. $\$ 78(\mathrm{~g})(1976)$. Implementing Federal Reserve Board regulations include: Regulation T, 12 C.F.R. $\$ \S 220.1-.8$ (1979); Regulation U, id. \$\$ 221.1-.4; Regulation G, id. $\S \S 207.1-.5 ;$ Regulation $\mathrm{X}$, id. $\$ \S 224.1-6$. 
federal margin requirements have been raised as a defense, state decisions conform closely to those of federal courts. ${ }^{60}$

Third, it has been asserted that state courts may be hostile to unfamiliar federal claims arising in familiar state law contract actions. ${ }^{70}$ While perhaps applicable to civil rights claims, ${ }^{71}$ the proposition that state courts deliberately seek to undermine the assertion of federal rights appears inapposite to Exchange Act claims. The Exchange Act fails to implicate inflammatory issues that might compel a state jurist to oppose an Exchange Act claim simply because it involves a federal rather than a state right. In light of the adoption of the USA in many states, the interests of the state and federal judicial systems in the rights of security holders appear to be coterminous. ${ }^{72}$

The fourth and most compelling argument against concurrent jurisdiction centers on the disparate impact of federal and state discovery provisions in the vindication of Exchange Act rights. What is gained by a federal removal scheme ${ }^{73}$ is lost by the concurrent jurisdiction proposal. Because a federal claimant would still prefer federal procedure, ${ }^{74}$ concurrent jurisdiction would encourage a race to the courthouse. Only if the federal plaintiff filed suit in federal court prior to the institution of the state proceeding could he de-

69. State and federal courts generally have held that borrowers cannot avoid liability on stock agreements that do not explicitly violate federal margin regulations. Compare Drasner v. Thomson McKinnon Sec., Inc., 433 F. Supp. 485 (S.D.N.Y. 1977) and Newman v. Pershing \& Co., 412 F. Supp. 463 (S.D.N.Y. 1975) with Gregory-Massari, Inc. v. Purkitt, 1 Cal. App. 3d 968, 82 Cal. Rptr. 210 (1969) and Billings Assocs., Inc. v. Bashaw, 27 A.D.2d 124, 276 N.Y.S.2d 446 (1967). But see Staley v. Salvesen, 35 Pa. D. \& C. 2d 318, 324-26 (Phil. County Ct. 1963) (plaintiff broker's failure to liquidate customer's cash account violated Regulation $T$ guidelines thereby permitting borrower to avoid liability). See generally Climan, Civil Liability Under the Credit-Regulation Provisions of the Securities Exchange Act of 1934, 63 CoRNELL L. REv. 206, 227-29 (1978).

70. See ALI STudy, supra note 45, at 167-68; Note, Collateral Estoppel, supra note 35, at 1282; Currie, supra note 45 , at 268.

Effectively insulated from federal court supervision or intervention, see 28 U.S.C. $\$ 2283$ (1976) (federal anti-injunction statute greatly restricts power of federal courts to enjoin state court proceedings); ALI STUDY, supra note 45, at 167-68 (Supreme Court and federal courts of appeals do not possess same "broad supervisory powers" over state courts that can be exercised with regard to inferior federal tribunals), a state court can employ dilatory tactics that may seriously impede a state litigant's federal rights, see, e.g., NAACP v. Flowers, 377 U.S. 288, 290.93 (1964) (Court opinion recites procedural devices utilized by Alabama courts to frustrate assertion of NAACP's federal defense to state law action).

71. See NAACP v. Flowers, 377 U.S. 288 (1964); ALI STUDY, supra note 45, at 167.68.

72. The growing identity of legal concepts in the securities field is a function of two factors: states that have adopted the USA have essentially codified many of the key provisions of the Exchange Act, see note 65 supra; and, common law and Exchange Act fraud claims have been unified through the common requirement of scienter, see Ernst \& Ernst v. Hoch felder, 425 U.S. 185, 193 (1976).

73. See pp. 106-0' supra.

74. See pp. 103-04 supra. 
rive the benefit of the liberal federal discovery rules. Although this second ALI proposal would clarify the respective functions of state and federal judges, litigants would still be wasting resources on the question of jurisdiction. Important attractions of exclusive jurisdiction-clarity and efficiency-would be lost.

\section{An Integrative Solution: State Court Counterclaim Jurisdiction With Federal Procedural Safeguards}

The problems illustrated by the Will scenario cannot be fully resolved by simply altering the allocation of Exchange Act jurisdiction to expand or restrict the role of the states. ${ }^{75}$ To ensure the vin-

75. Implicitly recognizing the failures of the proposed allocational solutions, a number of commentators have advocated modification of the rules of collateral estoppel. See, e.g., Note, Collateral Estoppel, supra note 35, at 1296; Comment, Exclusive Federal Jurisdiction: The Effect of State Court Findings, 8 STAN. L. REv. 439, 448-51 (1956) [hereinafter cited as State Court Findings]. Under these proposals, federal courts would not be bound by state determinations of fact and law pertaining to defenses based on exclusive federal acts or state laws that parallel exclusive federal legislation. See Note, Collateral Estoppel, supra note 35, at 1296 (preclusive effect should only be given to state adjudication of defenses premised on statutes that do not duplicate exclusive federal laws).

A "no-estoppel" rule would thus encourage a state court litigant to raise a federal defense without fear of the adverse impact on a subsequent federal action. However, the no-estoppel rule fails to resolve adequately the problems of bifurcated counterclaim adjudication. Separate state and federal suits would still be necessary in order to adjudicate fully all affirmative and defensive Exchange Act claims; the state defendant still would be required to expend funds and energies in the defense of one suit and prosecution of another. The no-estoppel provision also fails to serve judicial economy needs. In fact, federal courts following a no-estoppel format would be deprived of the benefit of previous fact finding. See Vernitron Corp. v. Benjamin, 440 F.2d 105, 108 (2d Cir.), cert. denied, 402 U.S. 987 (1971) (state determined facts "slould be welcomed [so as] to avoid the task of reconsidering issues which have already been settled by another competent tribunal'); Note, The Law of Fact: Findings of Fact Under the Federal Rules, 61 HaRv. L. REv. 1434, 1435 (1948) (federal courts seek to avoid "the time-consuming burden of finding the facts specially").

Moreover, this version of collateral estoppel fails to recognize that the boundary between state defenses that do and do not duplicate exclusive federal law has become increasingly indefinite. Although many of the USA provisions track federal securities law, see note 65 supra, several states have in turn modified specific USA sections, see 7A UNIForM LAws ANNotAted 563-66 (1978) \& 19-20 (Supp. 1979). As a result, federal courts will experience difficulties in determining which state defense findings should be accorded preclusive effect. Ambiguities in the distinctions between duplicative and nonduplicative state defenses are likely to lead to wasteful litigation as common law and Exchange Act fraud standards merge. See Ernst \& Ernst v. Hochfelder, 425 U.S. 185 (1976); Note, Administrative Collateral Estoppel: The Case of Subpoenas, 87 YALE L.J. 1247, 1263 (1978).

In addition, determinations on the basis of nonliberal state discovery of defenses that do not duplicate federal law could have serious prejudicial impact on a subsequent federal adjudication. In the course of adjudicating even nonduplicative state claims, the state court is almost certain to make factual determinations regarding many issues (e.g., representations made during the securities transaction). According to the Harvard proposal, such determinations should be accorded preclusive effect in federal court. See Note, 
dication of Exchange Act rights and to serve judicial economy, a scheme integrating procedural protection and clear jurisdictional pathways is necessary. Such an integrative approach would require state courts to adjudicate Exchange Act counterclaims utilizing federal procedural safeguards.

By resolving all elements of an Exchange Act dispute in one forum, counterclaim jurisdiction would remove duplicative litigation from the dockets of the federal and state systems. ${ }^{76}$ Moreover, plenary state court jurisdiction of counterclaims would minimize litigation costs for both the courts and the parties in interest. At the same time, the imposition of federal procedural safeguards, most notably discovery, would relieve concern about the limitations of state court adjudication.

Authority exists for the imposition of federal procedural safeguards in the state adjudication of Exchange Act counterclaims. When Congress conferred concurrent jurisdiction on state courts to hear Federal Employers' Liability Act [FELA] ${ }^{77}$ claims, it failed to address the issue of whether federal or state procedural rules should apply. ${ }^{78}$ The Supreme Court has held, however, that federal rules are applicable. ${ }^{79}$ The basis of this ruling was the Court's determination that restrictive local rules of procedure should not be allowed to frustrate the assertion of federally created rights in a state forum. ${ }^{80}$ The Court

Collateral Estoppel, supra note 35, at 1296. However, state findings pertaining to these questions will be relevant to federal Exchange Act claims. The proposal thus appears to allow such state findings to have an indirect but nevertheless binding effect on federal Exchange Act proceedings.

76. The strain on overworked federal judicial resources would be alleviated through the elimination of the need for an Exchange Act state defendant to file a parallel federal action. Furthermore, the Note proposal would shield the federal judiciary from the adjudication of time-consuming ancillary motions (e.g., motions to stay federal proceedings or enjoin state actions) incident to exclusive jurisdiction. Inferior federal courts would also have no appellate role to play with respect to state adjudication of Exchange Act counterclaims. The federal system would be implicated only by Supreme Court certiorari review. While reducing federal caseloads, state counterclaim jurisdiction will not impose a consequent "undue" burden on state tribunals. State courts are likely to find that counterclaim adjudication merely entails an additional remedy judgment premised on facts and issues already evolved by Exchange Act defense consideration. Cf. Bell, Crisis in the Courts: Proposals for Change, 31 VAND. L. REv. 3, 10 n.19 (1978) (resolution of Conference of [State] Chief Justices indicating that "state court systems are able and willing to provide needed relief to the federal court system").

77. 45 U.S.C. $\$ \$ 51-60$ (1976).

78. See id. $\$ 56$.

79. See Dice v. Akron C. \& Y.R.R. Co., 342 U.S. 359, 362-64 (1952); Brown v. Western Ry. of Ala., 338 U.S. 294, 296-99 (1949).

80. See Brown v. Western Ry. of Ala., 338 U.S. 294, 298-99 (1949), quoting Davis v. Wechsler, 263 U.S. 22, 24 (1923); Hill, Substance and Procedure in State FELA ActionsThe Converse of the Erie Problem?, 17 OHı ST. L.J. 384, 414 (1956) ("[i]n general it is undoubtedly desirable that a state court should give effect to federally-created rights substantially as a federal district court would. ..."). 
feared that nonliberal state provisions for pleading ${ }^{\$ 1}$ or jury trial ${ }^{82}$ would deprive FELA litigants of the federal procedural protections that are "part and parcel" 83 of their federally created rights. ${ }^{84}$ Based upon the Court's FELA decisions, Congress has the power to introduce federal procedural safeguards into the state court adjudication of Exchange Act defenses and counterclaims. ${ }^{85}$

81. See, e.g., Brown v. Western Ry. of Ala., 338 U.S. 294, 299 (1949) (complaint alleging negligence held sufficient to survive general demurrer despite contrary state ruling on the basis of "over-exacting local requirements for meticulous pleadings"); Note, State Enforcement of Federally Created Rights, 73 HARv. L. REv. 1551, 1561-62 (1960).

82. See, e.g., Dice v. Akron C. \& Y.R.R. Co., 342 U.S. 359, 362-64 (1952) (issue of fraudulent release in FELA negligence case should have been tried before jury despite contrary state practice); Note, supra note 81 , at $1562-64$.

83. Dice v. Akron C. \& Y.R.R. Co., 342 U.S. 359, 363 (1952).

84. Some commentators have suggested that the Court's concern for procedural protection is sharply limited to the context of FELA actions. See Hill, supra note 80, at 415; Comment, 50 Colum. L. REv. 385,388 (1950). Others have accorded the Court's FELA decisions a much more expansive impact. See note 85 infra (citing authorities); Note, Procedure Applicable To Suits in State Courts under Federal Act, 37 CoRnelL L.Q. 799, 804 (1952); 22 TENN. L. REv. 581, 584 (1952). As the Court's opinions in Brown and Dice, see notes 79-82 supra, fail to restrict explicitly the scope of permissible introductions of federal procedure into state adjudications of federal claims, a broad reading of the Court's rationale would appear justified. Cf. Note, Procedural Protection for Federal Rights in State Courts, 30 U. GiNN. L. REv. 184, 193-96 (1961) (uncertainty as to the extension of the Court's FELA approach); 27 N.Y.U. L. REv. 369, 372 (1952) (if Court intended to establish new procedural doctrine it "should have done so clearly and without equivocation") (footnote omitted).

85. As noted by Professor Wright, "even if the FELA cases are unique, they stand for the proposition that Congress has constitutional power to control the incidents of a state trial of a federal claim." C. Wright, Handoook of THE LAw of Federal Courts 196 (3d ed. 1976) (footnote omitted). Other commentators have expressed similar views on this issue, see, e.g., Note, Implied Rights, supra note 67, at 106 n.60.

As the FELA Supreme Court cases provide constitutional authority for the imposition of federal procedure, it is important to recognize that the alleged procedural inadequacies of state FELA adjudication do not impair the integrity of the proposed Exchange Act amendment. State FELA litigation has been sharply criticized for the failure of state courts to rule properly on the sufficiency of evidence needed to submit a FELA case to a jury. See, e.g., Alderman, What the New Supreme Court Has Done to the Old Law of Negligence, 18 LAw \& ConTEMP. Prob. 110 (1953). Indeed, the disparity in state, as well as federal, rulings has resulted in a volume of Supreme Court certiorari review felt by some members of the Court to be unjustifiably burdensome. See, e.g., Ferguson v. MooreMcCormack Lines, Inc., 352 U.S. 521, 524, 546 (1957) (Frankfurter, J., dissenting) (objecting to the grant of certiorari).

However, the alleged failings of the state courts in FELA cases is substantive and not procedural in origin. The range of state decisions on the sufficiency of evidence is attributable to the failure of both federal and state courts to articulate a clear standard of employer liability. Although nominally premised on a common law negligence standard, the threshold for FELA liability has been ambiguously lowered by judicial action to approximate strict liability in tort. See, e.g., Rogers v. Missouri Pac. R.R. Co., 352 U.S. 500,506 (1957) ("Under this statute the test of a jury case is simply whether the proofs justify with reason the conclusion that employer negligence played any part, even the slightest, in producing the injury or death for which damages are sought.") (emphasis added) (footnote omitted); Corso, How F.E.L.A. Became Liability Without Fault, 15 Crev.Mar. L. Rev. 344 (1966); Prosser, Handbook of The Law of Torts 536 (4th ed. 1971).

In direct contrast, the liability standard for Exchange Act fraud has been clearly re. 
Reference to the factual background of Will illustrates how the proposed experiment with state court adjudication of Exchange Act claims would sacrifice neither litigation economy nor procedural protection. Rather than being compelled to appear in duplicative federal and state actions, the Will state defendant under the proposed amendment could respond to the state law action by the unitary pleading of both defensive and affirmative Exchange Act claims. Assertion of an Exchange Act right would trigger the critical introduction of federal procedure into the state proceedings. With all elements of the dispute concentrated in one forum, the state court adjudication of both federal and state claims would attain the procedural status of res judicata and not collateral estoppel..$^{86}$

\section{Conclusion}

The efficiency values of exclusive federal jurisdiction have failed to survive the modern emphasis on the transactional case. This collision of procedural reforms has resulted in a jurisdictional pattern that disserves the courts and the Exchange Act litigants.

The original goals underlying the Act's jurisdictional plan need not be abandoned. Although the pristine clarity of exclusive jurisdiction is beyond recovery, an allocational and procedural approach that integrates state counterclaim jurisdiction with federal procedural safeguards would serve judicial economy interests in a manner consistent with the policies underlying exclusive federal jurisdiction.

defined. Recently, the Supreme Court explicitly rejected a negligence approach and instead imposed an "intent to deceive" test for $\$ 10 \mathrm{~b}$ liability. See Ernst \& Ernst v. Hochfelder, 425 U.S. 185, 193, 214 (1976). Properly characterized, the "substantive" law problems of FELA state litigation are thus not likely to extend to the state adjudication of Exchange Act defenses and counterclaims.

Indeed, the argument for the introduction of federal procedural safeguards is thus particularly compelling in the case of state court adjudication of Exchange Act counterclaims. If federal procedural protection is necessary to the proof of negligence in the FELA setting, see pp. 115-16 supra, similar procedural security would appear warranted for Exchange Act claims and defenses requiring proof of a higher liability standardscienter.

86. This Note's analysis of Exchange Act exclusive jurisdiction can be applied to other areas of exclusive federal jurisdiction. In each instance, however, the most desirable remedial model will be dependent upon the balance among the policies served by the jurisdictional allocation-such as the need for expertise-and the general goals of the jurisdictional scheme-such as the need for clarity. 